\title{
Model Pengembangan Strategi Komunikasi Bisnis untuk Mencapai Tujuan Pemasaran pada Usaha Kecil Menengah (Studi Kasus Pada Konsep Usaha Rumah Tangga Kerak Nasi)
}

\author{
Said Afriaris, Sry Windartini \\ Sekolah Tinggi Ilmu Indragiri Rengat, Indonesia \\ saidafriaris@stieindragiri.ac.id
}

\begin{abstract}
Abstrak
Konsep Usaha Rumah Tangga merupakan salah satu dari banyaknya usaha di Kabupaten Indragiri Hulu. Konsep Usaha Rumah Tangga yang bergerak di usaha Pembuatan "Kerak Nasi” di Desa Kota Lama Kecamatan Rengat Barat. Untuk mendapatkan konsumen dengan menggunakan strategi komunikasi bisnis yang di lakukan dalam sebuah kegiatan bisnis dan strategi yang di gunakan oleh pengusaha-pengusaha untuk mencapai tujuan yang di harapkan yakni tujuan pemasaran dengan menggunakan strategi komunikasi bisnis. Penelitian ini menggunakan metode penelitian deskriptif kualitatif dengan melakukan pengamatan langsung terhadap objek yang diteliti (paradigma post positivisme) serta teknik pengumpulan data menggunakan wawancara dan observasi dengan pihak pembuat usaha dengan memakai informan utama dan informan pendukung. Hasil penelitian dapat disimpulkan bahwa : (1) Dalam tahapan Attention dengan memperhatikan permintaan produk dari konsumen, hal ini berpengaruh positif terhadap kesan pertama bagi pembeli. (2) Pada tahapan Interest dengan menanamkan kepercayaan konsumen untuk mempermudah dan membuat keputusan. (3) Dalam tahap Desire dengan meyakinkan konsumen melalui keunggulan dan penawaran harga khusus agar memiliki hasrat untuk membeli. (4) Dalam tahap Action dengan memastikan konsumen yakin dan percaya kualitas produk sehingga keputusan untuk membeli produk adalah keputusan yang tepat.
\end{abstract}

Kata Kunci : Komunikasi, Komunikasi Bisnis, Model A.I.D.A

\section{Pendahuluan}

Masyarakat modern saat ini memiliki informasi yang luas dengan seiring berkembangnya zaman teknologi informasi. Berbagai industry bisnis saat ini dituntut untuk merencanakan bagaimana strategi bisnis produk yang dihasilkannya agar mampu menghadapi persaingan pasar global saat ini. Untuk bersaing di pasar global seperti sekarang ini, dibutuhkan strategi bisnis produk yang kreatif, variatif serta komunikatif yang dikemas melalui strategi komunikasi bisnis. Strategi komunikasi merupakan paduan antara perencanaan komunikasi dengan manajemen komunikasi dalam mencapai tujuan yang ditetapkan (Effendy.2000). Untuk mencapai tujuan, strategi komunikasi harus mampu menunjukkan bagaimana operasionalnya secara praktis harus dilakukan. Jadi, strategi komunikasi adalah keseluruhan perencanaaan, taktik, cara yang akan dipergunakan guna melancarkan komunikasi dengan memperhatikan keseluruhan aspek dalam proses komunikasi untuk mencapai tujuan.

Usaha mikro, kecil dan menengah (UMKM) merupakan pelaku bisnis yang bergerak pada berbagai bidang usaha, yang menyentuh kepentingan masyarakat. Undang- Undang Nomor 20 Tahun 2008 tentang Usaha Mikro, Kecil dan Menengah (UMKM). Usaha Mikro adalah usaha produktif milik orang perorangan dan/atau badan usaha perorangan yang memenuhi kriteria Usaha Mikro sebagaimana diatur dalam Undang-Undang. Usaha Kecil adalah usaha ekonomi produktif yang berdiri sendiri, yang dilakukan oleh orang perorangan atau badan usaha yang bukan merupakan anak perusahaan atau bukan cabang perusahaan yang 
dimiliki, dikuasai, atau menjadi bagian baik langsung maupun tidak langsung dari usaha menengah atau usaha besar yang memenuhi kriteria Usaha Kecil sebagaimana dimaksud dalam Undang-Undang.

Kabupaten Indragiri Hulu Khususnya Kecamatan Rengat barat banyak sekali pelaku Usaha Rumah Tangga yang menghasilkan produk. Usaha yang dijalankan beraneka ragam, dari berbagai jenis makanan maupun minuman. Pada penelitian yang dilakukan ini hanya berfokus kepada Usaha Rumah Tangga yang menghasilkan produk makanan "Kerak Nasi" di desa Kota Lama Kecamata Rengat Barat yang menghasilkan produk yang ada dimasyarakat. Melalui pra survey yang dilakukan peneliti ke lokasi usaha, berikut data hasil Penjualan per tahun dari usaha kerak nasi di tabel berikut.

\section{Tabel. 1. Hasil Penjualan produk "Kerak Nasi” Desa Kota Lama dari tahun 2016-} 2019

\begin{tabular}{|c|c|c|}
\hline No & Tahun & $\begin{array}{c}\text { Jumlah Konsumen yang Membeli } \\
\text { (Orang) }\end{array}$ \\
\hline 1 & 2016 & 625 \\
\hline 2 & 2017 & 998 \\
\hline 3 & 2018 & 583 \\
\hline 4 & 2019 & 698 \\
\hline
\end{tabular}

Sumber : Data survei Lapangan. Tahun 2020

Berdasarkan tabel diatas dilihat bahwa hasil penjualan dari usaha kerak nasi ini omset yang diterima mengalami perubahan tiap tahunnya bahkan terjadi penurunan pada tahun 2018 dengan jumlah konsumen sebanyak 583 orang. Hal disebabkan karena kurangnya strategi dalam pemasaran produk yang berpengaruh terhadap kelangsungan usaha rumah tangga. Sebagai pelaku usaha harus mampu meningkatkan daya minat dari masyarakat untuk membeli produk yang dijual dengan mempertimbangkan selera dari konsumen.

Adapun tujuan dilakukan penelitian ini adalah. 1) Untuk menarik Perhatian (attention) dalam strategi komunikasi bisnis untuk mencapai tujuan pemasaran. 2) Untuk membangun minat (interest) dalam strategi komunikasi bisnis untuk mencapai tujuan. 3) Untuk meningkatkan keinginan/hasrat (deisre) dalam strategi komunikasi bisnis untuk mencapai tujuan pemasaran. 4) Untuk memotivasi tindakan (action) dalam strategi komunikasi bisnis untuk mencapai tujuan pemasaran.

\section{Telaah Pustaka}

\section{Komunikasi}

Menurut Himstreet dan baty (2006). dalam "Business Communications": Principles and Method, komunikasi adalah suatu pross pertukaraninformasi antara individu melalui suatu system yang biasa (lazim), baik dengan simbol, sinyal maupun perilaku atau tindakan.

Menurut Ahmad Sihabudin dan Rahmi Winangsih (2012:17) Komunikasi merupakan pengetahuan dan ketrampilan yang harus dimiliki dalam berinteraksi dan berkehidupan antar manusia.

Proses Komunikasi

Menurut Bovee and Thill (2010) dalam buku Business Communicatin Today be, proses komunikasi terdiri atas enam tahap, yaitu :

1. Pengirim Mempunyai Suatu Ide/Gagasan

Sebelum proses penyampaian pesan dilakukan, pengirim pesan harus menyiapkan ide atau gagasan apa yang ingin disampaikan kepada pihak lain atau komunikan. Ide dan 
gagasan menjadi hal penting dalam komunikasi suatu bisnis, karena untuk dapat menarik perhatian konsumen terhadap produk atau jasa yang ditawarkan.

2. Pengirim Mengubah Ide Menjadi Sebuah Pesan

Agar ide diterima dan dimengerti secara sempurna, pengirim pesan harus memperhatikan beberapa hal, yaitu subjek (apa yang ingin disampaikan), maksud (tujuan), komunikan dan latar belakang budaya.

3. Pengirim Menyampaikan Pesan

Setelah mengubah ide menjadi suatu pesan, selanjutnya menyampaikan pesan melalui berbagai saluran yang ada kepada penerima pesan. Dengan menggunakan suatu media elektronik ataupun media massa dengan contoh iklan yang menarik.

4. Penerima Menerima Pesan

Komunikasi antara seseorang dengan orang lain akan terjadi, bila pengirim (komunikator) mengirimkan suatu pesan dan penerima (komunikan) menerima pesan tersebut.

5. Penerima Menafsirkan Pesan

Setelah penerima menerima pesan, tahap berikutnya adalah bagaimana ia dapat menafsirkan pesan. Suatu pesan yang disampaikan pengirim harus mudah dimengerti dan tersimpan di dalam benak pikiran penerima pesan.

6. Penerima Harus Memberikan Tanggapan dan Umpan Balik ke Pengirim Umpan balik (feedback) adalah penghubung akhir dalam suatu mata rantai komunikasi. Umpan balik tersebut merupakan tanggapan penerima pesan yang memunginkan pengirim untuk memulai efektivitas suatu pesan.

Komunikasi Bisnis

Menurut Djoko Purwanto (2011:4) mengungkapkan Komunikasi bisnis adalah komunikasi yang digunakan dalam dunia bisnis yang melibatkan dua orang atau lebih dan proses pemindahan pesannya dapat dilakukan dengan menggunakan cara-cara komunikasi yang lebih biasa dilakukan oeh seseorang melalui lisan, tulisan maupun sinyal-sinyal mencakup berbagai macam bentuk komunikasi baik komunikasi verbal maupun nonverbal.

Strategi . Persuasi yang efektif mencakup beberapa komponen penting yaitu : (Djoko Purwanto. 2011:165)

1. Menetapkan Kredibilitas

Kredibilitas ditentukan oleh sejauh mana tingkat kepercayaan dan keandalan anda di hadapan audiens diragukan. Mereka akan cenderung skeptis dan tidak akan menerima begitu saja terhadap yang disampaikan, oleh karena itu harus bisa mengatasi calon konsumen yang memiliki sikap skeptic tersebut. Kredibilitas merupakan kapabilitas untuk dapat dipercaya oleh orang lain. Tanpa kredibilitas upaya untuk melakukan persuasi akan tampak seperti bentuk tipuan.

2. Kerangka Argumentasi

Setelah cukup mengumpulkan berbagai fakta, bukti dan temuan lainnya selanjutnya membuat kerangka argumentasi. Kebanyakan pesan-pesan persuasi mengikuti rencana orgnisasional AIDA (Attention, Interest, Desire, Action).

3. Memilih Daya Pemikat

Kebanyakan pesan-pesan persuasif menggunakan daya pemikat dengan logika (Logical appeals) dan daya pemikat yang emosional (Emotional appelas) untuk melakukan persuasi. Keseimbangan antara keduanya bergantung pada empat faktor yaitu :
a. Tindakan yang anda harapkan
b. Harapan Audiens
c. Tingkat resistensi yang harus anda atasi
d. Seberapa jauh anda mampu menjual ide/gagasan anda tersebut 


\section{Model AIDA}

Rehman dkk (2014) menjelaskan model AIDA sering digunakan untuk mengukur keefektifan promosi.

Dalam (Rawal, 2013) AIDA adalah sebuah model untuk mengukur efektifitas dari kegiatan promosi, mencakup empat tahap yaitu Attention, Interest, Desire, dan Actions.

Menurut (Kotler, 2009:179) menjelaskan teori AIDA (Attention, Interest, Desire, Action) merupakan suatu pesan yang harus mendapatkan perhatian, menjadi ketertarikan, menjadi minat, dan mengambil tindakan.Teori ini menyampaikan dari kualitas pesan yang baik.

\section{Metodologi Penelitian}

\section{Objek Penelitian}

Kegiatan penelitian ini dilakukan pada "Usaha Rumah Tangga Kerak Nasi" di Desa Kota Lama Kecamatan Rengat Barat Kabupaten Indragiri Hulu

\section{Desain Penelitian}

Pada penelitian ini menggunakan metode kualitatif menurut Burhan Bungin (2011), yaitu sebagai berikut:

Pengumpulan Data (Data Collection)

Pengumpulan data merupakan bagian integral dari kegiatan analisis data. Kegiatan pengumpulan data pada penelitian ini adalah dengan menggunakan wawancara dan studi dokumentasi.

Reduksi Data (Data Reduction)

Reduksi data, diartikan sebagai proses pemilihan, pemusatan perhatian pada penyederhanaan dan transformasi data kasar yang muncul dari catatan-catatan tertulis di lapangan. Reduksi dilakukan sejak pengumpulan data dimulai dengan membuat ringkasan, mengkode, menelusur tema, membuat gugus-gugus, menulis memo dan sebagainya dengan maksud menyisihkan data/informasi yang tidak relevan.

Display Data

Display data adalah pendeskripsian sekumpulan informasi tersusun yang memberikan kemungkinan adanya penarikan kesimpulan dan pengambilan tindakan. Penyajian data kualitatif disajikan dalam bentuk teks naratif. Penyajiannya juga dapat berbentuk matrik, diagram, tabel dan bagan.Verifikasi dan Penegasan Kesimpulan (Conclution Drawing and Verification).

\section{Hasil dan Pembahasan}

Hasil penelitian yang dilakukan. Peneliti mendeskripsikan dengan menggunakan strategi komunikasi bisnis Konsep Usaha Rumah Tangga Kerak Nasi dalam mencapai tujuan pemasaran produk. Dengan memaparkan beberapa dari hasil observasi dan wawancara mendalam (depth interview) dengan key informan dan informan. Dalam menentukan key informan, peneliti melakukan pertimbangan bahwa karakteristik key informan dianggap memiliki banyak informasi mengenai Strategi Komunikasi Bisnis pada Konsep Usaha Rumah Tangga Kerak Nasi. Key informan pada penelitian ini adalah "Ibuk Rismawati Iris" yang merupakan pendiri sekaligus pengelola bisnis sejak berdirinya Konsep Usaha Rumah Tangga Kerak Nasi pada Awal Tahun 2015 hingga sekarang ini. Dengan merangkap selaku karyawan dalam usahanya, dimana setiap harinya ibuk Risma Iris membuat serta memasarkan produknya ketika ada konsumen yang memesan, dalam penelitian ini Ibuk Risma yang kesehariannya dipanggil Buk Iris berperan menjadi key informan dalam memberikan informasi lebih banyak seputar strategi komunikasi bisnis Konsep Usaha Rumah Tangga Kerak Nasi kepada peneliti. 
Selain key informan, peneliti juga melakukan wawancara mendalam dengan informan pendukung lainnya yaitu konsumen yang pernah menggunakan produk Usaha Rumah Tangga Kerak Nasi. Penulis memilih informan ini karena lebih paham dan mengetahui mengenai strategi komunikasi bisnis yang di gunakan Konsep Usaha Rumah Tangga Kerak Nasi untuk mencapai tujuan pemasaran. Kemudian, hasil observasi dan wawancara peneliti dengan key informan dan informan di check kebenarannya berdasarkan teknik uji Reliabilitas data untuk mengecek kebenaran data yang diberikan oleh pihak Konsep Usaha Rumah Tangga Kerak Nasi dan konsumen sesuai dengan kenyataan yang terjadi dalam penelitian strategi komunikasi bisnis untuk mencapai tujuan pemasaran. Selain itu, peneliti juga menggunakan triangulasi sumber sebagai perbandingan kebenaran data yang diberikan narasumber terhadap fakta yang terjadi di Konsep Usaha Rumah Tangga Kerak Nasi, konsumen dan masyarakat. Seperti hasil wawancara yang di jelaskan oleh Ibu Rismawati Iris sebagai Owner:

"Untuk komunikasi bisnis di Concept sendiri saya anggap konsumen itu baik konsumen yang lama ataupun baru itu bukan sekedar konsumen, tapi dianggap sebagai teman juga, ketika konsumen datang kita ajak berbicara mulai dari pendekatan biar akrab. Hal ini dilakukan konsumen tidak merasa malu dan ragu untuk datang kesini, dan bisa merasa nyaman ketika ada disini, jadi apapun yang di inginkan konsumen kita bisa mengaplikasikannya. Dan juga dalam segi pelayanan saya melayani konsumen dengan baik agar mendapatkan kesan terbaik dari konsumen".

Hasil wawancara menjelaskan bahwa konsep usaha yang dilakukan beranggapan bahwa konsumen adalah teman, tidak adanya batasan antara konsumen dengan konsep Usaha Rumah Tangga Kerak Nasi. Hal ini, ternyata menguntungkan, karena dengan menerapkan strategi komunikasi bisnis terhadap konsumen membuat konsumen tidak merasa malu, tidak sungkan dan merasa nyaman ketika berada di lokasi usaha.

Strategi yang tepat dapat membantu mengembangkan usaha, meningktakan dan mempertahankan usaha untuk ke depannya. Belakangan ini, hampir semua bidang bisnis tumbuh pesat tanpa terkecuali. Oleh karena itu, perusahaan akan sangat terbantu dengan kiat-kiat khusus dalam memasarkan produknya. Di Usaha Rumah Tangga Kerak Nasi bukan hanya menerapkan strategi komunikasi bisnis terhadap konsumen, tapi juga menerapkan Konsep AIDA sebagai strategi komunikasi bisnis untuk mencapai tujuan pemasaran dan keahlian berkomunikasi yang baik, karena dengan berkomunikasi yang baik dapat membantu untuk meningkatkan produk yang ada dengan menarik minat konsumen. Tetapi, tidak semua komunikasi yang dilakukan melalui tatap muka langsung dengan konsumen, adapun komunikasi yang dilakukan lainnya adalah melalui media sosial dan mesengger seperti facebook, layanan sms, telepon, whats App sebagai pelengkap.

Setiap bisnis mempunyai tujuan yang sama pada dasarnya, yaitu mendapatkan keuntungan dan menguasai pasar. Usaha Rumah Tangga Kerak Nasi menerapkan Konsep AIDA guna menarik konsumen yang baru dan mempertahankan konsumen yang sudah ada untuk tetap menggunakan produk dari Usaha Rumah Tangga Kerak Nasi. Banyak tantangan yang harus dihadapi salah satunya persaingan dengan usaha rumah tangga lainnya. Konsep Usaha Rumah Tangga Kerak Nasi menggunakan Model AIDA sebagai strategi komunikasi bisnis. Strategi Model AIDA mejelaskan tahapan proses respon konsumen dalam mengambil keputusan yang terdiri dari Attention, Interst, Desire, Action. (Moriarty, Mitchel, Wells, 2015 hal 132)

Attention (menarik perhatian)

Penulisan surat-surat penjualan pada mulanya dimulai dengan bagaimana cara menarik perhatian konsumen. Dalam kegiatan usaha ini untuk menarik perhatian konsumen melalui media sosial, selain itu untuk menarik perhatian konsumen diantaranya dengan 
menekankan contoh produk terbaru yang dipasarkan. Untuk menarik perhatian dapat juga dilakukan dengan memajang foto di media sosial. Menjadi pengikut pada akun media sosial lainnya untuk membuat diri anda / bisnis anda diketahui orang lain. Ikutilah orang-orang / bisnis yang terkenal. langkah ini, anda tidak hanya menjadi pengikut pasif tapi aktif memberikan komentar positif terhadap postingan dari akun teman anda. Menurut Owner dari Usaha Rumah Tangga Kerak Nasi dalam menarik perhatian konsumen.

"Untuk menarik perhatian konsumen saya memajang foto hasilan produk rumah tangga saya melalui media sosial. Dimana hasil produk terdahulu yang biasa saja sekarang saya tampikan menggunakan kemasan terbaru dan membuat logo yang tertera di dalam kemasan produk".

Berikut pernyataan "Eka" konsumen yang berada di sekitar tempat usaha:

"Saya rasa dari segi kemasan produk yang ditawarkan sekarang sudah berubah dari yang sebelumnya yang tidak menggunakan logo dan kemasan yang bagus sekarang sudah menghasilkan produk yang bagus, saya rasa sangat baik dalam memasarkan produk untuk menarik perhatian konsumen.

Pernyataan dari "Buk Novi” konsumen lain mengenai Usaha Rumah Tangga Kerak Nasi:

"Kalau sekarang saya lihat kemasan produk lebih menarik perhatian para konsumen. Dimana tidak sepeti dahulu yang belum menggunakan kemasan bagus serta belum ada nama khusus dari usaha tersendiri.

Beradasarkan pernyataan di atas, dimana menarik perhatian konsumen dengan merubah bentuk kemasan juga sangat penting dalam usaha. Attention sangat menentukan apakah konsumen akan tertarik atau tidak dari produk yang ditawarkan.

Interest (Membangun Minat)

Membangun minat konsumen perlu menekankan titik penjualan produk, dengan meyakinkan konsumen bahwa produk yang dihasilkan memiliki harga relatif murah, tahan lama atau sejenisnya. Dalam hal ini perlu melihat apa yang dilakukan oleh pesaing atau usaha sejenisnya yang membedakan produk yang dihasilkan dengan usaha sejenisnya

Berikut menurut Owner dalam membangun minat konsumen :

"Dalam hal ini pertama saya kurang percaya diri dari produk yang saya buat, karena banyak produk rumahan yang sejenisnya seperti rengginang yang terbuat dari bahan Ketan yang lebih dikenal masyarakat. Tetapi saya coba dengan mengenalkan produk yang saya buat berbeda dengan yang lainnya terbuat dari beras yang dimasak langsung, dan dijadikan kerak nasi. Saya mersa produk yang dihasilkan dengan bahan yang berbeda diminati oleh banyak orang. Serta saya menampilkan gambar produk yang dihasilkan sesuai dengan yang sebenarnya. Hal ini terbukti memberikan pengaruh positif terhadap daya Tarik calon pembeli”.

Berikut pernyatan dari "Buk Novi" konsumen mengenai Minat untuk membeli yang di tawarkan.

"Kalau saya sih tertariknya dengan roduk ini karena memang kerak nasi jarang digunakan sebagai produk yang dijual masyarakat. Dari produk yang dihasilkannya ini saya tertarik untuk mencobanya".

Dari penjelasan konsumen diatas dapat dijelaskan bahwa produk yang ditawarkan secara tidak langsung memiliki keunggulan tersendiri, yaitu dimana bahan baku beras yang digunakan jarang sekali dijadikan produk usaha rumah tangga.

Desire (Meningkatkan Hasrat)

Untuk lebih meningkatkan hasrat konsumen terhadap produk yang ditawarkan dapat dilakukan dengan membuat tagline yang dapat menimbulkan keinginan dan ketertarikan untuk membeli. Dalam hal ini pada saat melakukan promosi melalui foto 
sampaikan pula manfaat dan efek yang bisa didapat saat menggunakan produk yang ditawarkan. Berikan promosi-diskon khusus, beli dua dapat satu, beli banyak buat pesanan acara harga khusus, pemesanan paling awal mendapatkan diskon/bonus, dll. Perbarui media sosial "posting pada wall" secara teratur. Memantau komentar dan umpan balik dari para pengikut dan menanggapi dengan cepat. Menawarkan layanan pelanggan pra-penjualan dengan baik.

Berikut pernyataan "Reza" selaku konsumen yang pernah memesan Produk Kerak Nasi.

"Produk sudah berubah dari kemasan biasa sesuai kebutuhan, sekarang sudah berbentuk kemasan dengan harga terlampir di kemasan yaitu Rp. 10.000 hingga RP. 15.000, perbungkusnya dan sudah ada logo. Saya memesan untuk acara keluarga, dimana dalam hal ini untuk pemesanan banyak, memang harga khusus yang diberikan, lebih murah dan dikasih bonus jugak dan ini yang kedua kalinya saya memesan produk ini untuk acara keluarga"

Action (Memotivasi Tindakan)

Setelah mampu menumbuhkan minat dan hasrat konsumen, langkah berikutnya adalah bagaimana anda mampu memotivasi tindakan konsumen agar konsumen melakukan tindakan untuk melakukan pembelian, pada tahapan ini yang dapat dilakukan adalah dengan mengenali target pasar yang dibidik. Proses pemesanan yang jelas dalam bentuk gambar untuk memudahkan pengunjung memahami cara pemesanan. Informasi tentang opsi pembayaran (transfer bank, kartu kredit, Cash On Delivery). Pilihan Pengiriman (jasa kurir/diantar langsung) hal ini dapat meningkatkan kemampuan UKM dalam menggunakan media sosial sebagai memotivasi tindakan dari konsumen.

Berikut pernyataan dari owner ketika menjalankan kegiatan promosinya.

"Ibuk Iris" lebih memilih mengantarkan langsung pesanan yang dipesan oleh konsumen sekaligus bentuk promosi usaha "Kerak Nasi". mengenai promosi :"Langkah yang dilakukan dalam promosi untuk meningkatkan penjualan kita juga harus terus banyak inovasi baru agar tidak tertinggal dari usaha rumah tangga lainnya dan juga meningkatkan kualitas seperti pelayanan pesanan dalam banyak diberikan potongan harga dan bisa di antar ke alamat".

Pernyataan dari konsumen "Novidah" hal memotivasi tindakan:

"Saya mengetahui promosi usaha "kerak nasi" dari salah satu media sosial ibuk Iris, karena tempat saya lumayan jauh dari usaha ini, Ibuk Iris bersedia mengantarkan ke alamat saya tinggal dan harga juga bisa diskon karena saya pesan 10 bungkus. Ini yang menjadi kedekatan saya terhadap ibuk iris karena dia bisa langsung mengantarkannya serta menawarkan diskonnya secara langsung".

\section{Pembahasan}

Attention (Menarik Perhatian)

Mulai dari hirarki respon konsumen menaruh perhatian terhadap produk atau layanan kita sajikan, sampai respon aksi kosumen untuk memakai produk atau layanan kita lengkap disini. Tahap Attention AIDA berarti menaruh perhatian. Dimana tahap ini adalah tahap yang paling krusial namun sering kali dilupakan, Promosi yang tergolong elemen penting dalam pemasaran. Sebuah alat promosi haruslah menghipnotis konsumen, baik barang ataupun jasa yang kita tawarkan bisa tembus satu tujuan, yaitu terjual. Pasalnya media sosial adalah lalu lintas masyarakat untuk berkomunikasi yang mulai merambah sebagai lalu lintas pasar. Skenario promosi yang seolah mengikat konsumen untuk menaruh perhatian dengan produk maupun jasa kita di media sosial adalah wajib hukumnya. Baik media visual maupun tulisan, bilik iklan akan dilirik calon konsumen yang awalnya penasaran dan kemudian memancing keingintahuan calon konsumen untuk melihat produk 
maupun jasa yang dipasarkan. Elemen ini penting untuk calon konsumen ke tahap selanjutnya.

Interest (Membangun Minat)

Beralih setelah menarik perhatian calon konsumen, buatlah calon konsumen tertarik atau Interest dalam konsep AIDA. Ketertarikan disini dimaksud ketika calon konsumen mengumpulkan informasi tentang barang atau jasa yang dipasarkan. Paparkan keunggulan produk atau jasa kita dibanding produk maupun jasa lain. Suguhkan profil barang atau jasa dengan dipertajam lagi dengan sisipan pesan - pesan positif dari konsumen yang telah memakai produk kita dengan maksud untuk meyakinkan pada calon konsumen bahwa produk atau jasa yang dipasarkan memang lebih berkualitas dan berbeda dari produkproduk yang lain yang telah banyak dipasarkan dilingkungan masyarakat.

Dsire (Meningkatkan Hasrat)

Standar pemasaran konsep AIDA selanjutnya Desire, yang berarti berniat. Alat pemasaran yang dipilih lewat media sosial akan menjadi lebih potensial dan jauh lebih tepat ketika bisa mendorong keinginan calon konsumen untuk memakai barang atau jasa yang dipasarkan. Rasio persaingan pemasaran di media sosial memang sangat tinggi. Sebagai calon konsumen tentu akan menganalisa lebih dari satu produk dari pesaing lain. Sederhananya, konsumen butuh pendorong atau motivasi untuk berhasrat memilih membeli produk kita. Dari sini tonjolkan bahwa calon konsumen memang membutuhkan produk kita.

Action (Memotivasi Tindakan)

Proses pemasaran terbilang sukses ketika respon calon konsumen sesuai goal, membeli. Di dalam konsep AIDA disebut Action. Penawaran nilai tambah biasanya menjadi panggilan calon konsumen untuk melakukan tindakan membeli. Tidak berhenti disini, senantiasa menjaga kepuasan konsumen dan kontinyu dalam berpromosi akan senantiasa menarik pelanggan sebanyak-banyaknya. Saat ini AIDA telah bertambah menjadi AIDA(S). Ditambah dengan $\mathrm{S}$ dimana $\mathrm{S}=$ Satisfaction (Kepuasan). Buat dan jagalah kepuasan dan pengalaman yang menyenangkan dari prospek yang telah menjadi pelanggan tersebut agar konsumen membeli produk/jasa kita kembali dan mereferensikan kepada teman-temannya untuk bisnis kita dan membuat produk semakin besar meskipun karena dipercayai word of mouth (mulut ke mulut) merupakan salah satu metode iklan yang efektif. Karena jenis metode iklan seperti itu, merupakan bentuk dari suatu loyalitas konsumen terhadap produk yang memberikan kepuasan akibat dari pelayanan prima yang dipersembahkan kepada konsumen serta loyalitas tersebut-lah yang memiliki nilai tinggi atau dalam kata lain mahal. Sehingga, sebenarnya apapun jenis metode pemasaran yang akan kita gunakan, semahal apapun itu akan menjadi percuma jika pelanggan tidak puas. Jadi, berusahalah membuat pelanggan puas karena pada akhirnya, hal tersebutlah yang menjadi tujuan utama dari setiap usaha dalam membuat produk/pelayanan prima.

\section{Kesimpulan}

Dari hasil analisa data dalam penelitian ini, maka diperoleh kesimpulan bagaimana strategi komunikasi bisnis menggunakan model "AIDA" untuk mencapai suatu tujuan pemasaran dengan menggunakan "studi kasus pada usaha rumah tangga kerak nasi" yaitu.

a. Dalam tahap Attention (menaruh perhatian). Telah memperhatikan penawaran yang dilakukan calon pembeli dengan memperhatikan permintaan produk, cara bicara, sikap serta layanan hantaran produk. Hal ini berpengaruh positif terhadap kesan pertama bagi pembeli.

b. Dalam tahap "Interest" (ketertarikan). Konsep usaha ini telah menanamkan kepercayaan kepada calon pembeli dengan memberikan jalan untuk mempermudah 
pembeli mendapatkan dan membuat keputusan serta melakukan pendekatan kepada konsumen.

c. Tahap "Desire" (berhasrat/niat). Kegiatan ini dapat meyakinkan konsumennya dengan hasil produk yang ditawarkan melalui keunggulan dan penawaran harga dari produk sehingga konsumen dapat berpikir dan mengambil keputusan dengan niat untuk membeli.

d. Dalam tahap "Action" (memutuskan untuk membeli) dalam konsep ini dimana Usaha Rumah Tangga Kerak Nasi dapat memastikan bahwa konsumen yakin dan percaya kualitas produk dan dengan memberikan penawaran yang baik, sehingga tidak dapat ditolak oleh konsumen, bahwa keputusan untuk membeli produk adalah keputusan yang tepat.

\section{DAFTAR PUSTAKA}

[1] Bovee dan Thill. (2010). Business Communication Today, New Jersey: Pearson Education, Inc.

[2] Bungin,Burhan, 2009 . Metodelogi Penelitian Kualitatif, Jakarta : Kencana Perdana Grup.

[3] Choirunnisak. Penerapan Analisis SWOT Dalam Strategi Pemasaran Produk Tabungan.

[4] Hermawan,Agus, 2012 . Komunikasi Pemasaran, Jakarta : Erlangga.

[5] Himstreet dan Baty, Tahun 2006, Bussiness Communications. Jakarta: PT Gramedia Pustaka Utama.

[6] Kotler,Philip \& Gary Armstrong, 2008 . Prinsip-prinsip Pemasaran, Jakarta : Erlangga edisi 12.

[7] Kotler,Philip \& Kevin Lane Keller, 2012 . Manajemen Pemasaran. Jakarta: Erlangga.

[8] Purwanto,Djoko, 2012 . Komunikasi Bisnis. Jakarta : Erlangga, Jakarta.

[9] Purwanto,Djoko, 2006 . Komunikasi Bisnis. Edisi III Jakarta : Erlangga , Jakarta.

[10] Sandra Moriarty, Nancy Mitchell, William Wells. 2015. Advertising (edisi kedelapan). Jakarta:Perenada Media Group.

[11] Suhartini, Jurnal Penelitian Analisa SWOT Dalam Menentukan Strategi Pemasaran Pada Perusahaan. 2012

[12] Sihabudin,Ahmad \& Rahmi Winangsih, 2012 . Komunikasi Antar Manusia. Serang : Pustaka Getok Tular.

[13] Undang-undang No 20 Tahun 2008, Usaha Mikro, Kecil dan Menengah (UMKM). 